\title{
EFFECTS OF PULSATING WATER JET ON ALUMINIUM ALLOY WITH VARIOUSLY MODIFIED SURFACE
}

\author{
Jiř́ Klich, Dagmar Klichová, Petr Hlaváček
}

Original scientific paper

The paper deals with the topic of the determination of erosion effects of a pulsating water jet impinging the surface of aluminium alloy samples treated by various techniques (rough and fine milling, planing and rolling). The influence of the initial surface topography on the final topography of the sample exposed to the pulsating water jet was investigated. Erosion of surface layers was analysed and discussed in relation to the traversing velocity of the jet. It was found that initial surface properties have a significant impact on the final topography. Degree of the surface erosion was determined by the measurement of the surface parameter $R a$.

Keywords: material erosion; pulsating water jet; surface topography

Učinci pulsirajućeg mlaza vode na aluminijsku leguru s različito modificiranom površinom

Izvorni znanstveni članak Rad se bavi određivanjem učinaka erozije pulsirajućeg vodenog mlaza koji udara na površinu uzoraka od aluminijske legure obrađenih različitim postupcima (grubo i fino glodanje, blanjanje i valjanje). Ispitivao se utjecaj početne topografije površine na završnu topografiju uzorka izloženog pulsirajućem vodenom mlazu. Analizirala se erozija površinskih slojeva u odnosu na brzinu kojom ih mlaz prelazi. Ustanovilo se da početna svojstva površine značajno utječu na završnu topografiju. Stupanj erozije površine određen je mjerenjem površinskog parametra $R a$.

Ključne riječi: erozija materijala; pulsirajući vodeni mlaz; topografija površine

\section{Introduction}

Over a hundred years, researchers have been interested in the interaction of a liquid with a solid. One of the first researchers dealing with this subject was Cook [1] who wrote his article on the surface erosion in 1928. He clearly recognized the importance of the water hammer pressure.

Although the pulsating water jet (PWJ) has been successfully used for several industrial applications, the fundamentals of the technique remains unclear. Pulsating water jet is an extension of the conventional (continuous) jet, consisting of an array of high-speed water pulses. When a pulsating water jet impinges a target, the momentum flux through the nozzle is not transmitted to the target material as a steady force, but as a discontinuous sequence of impacts, creating high momentary stresses in the impingement zone. As a result, the peak pressure acting on the surface is not the stagnation pressure, but the significantly higher water hammer pressure [2].

There are several ways how to create the pulsating water jet as shown, for instance, in [3]. It can be done using mechanical interrupters, self-resonating systems, jets modulation by the piezoelectric magnetostrictive effects, jet disruption by electric discharge, laser based pulsating of water jets, etc. In our case, the system for the generation of acoustic pulsations developed at the

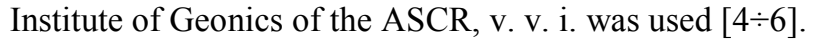

The pulsating water jets are generated by sufficiently high pressure pulsations in pressure water in the upstream direction to the nozzle exit. In the nozzle, the pressure pulsations change into velocity pulsations and the jet emerges from the nozzle exit as a continuous jet with variable axial velocity. Owing to the variable velocity, the jet is formed into pulses at a certain stand-off distance towards the nozzle exit (so called forced break-up length of the jet) and it starts acting as a pulsating jet. Exploitation of effects related to the water pulses impingement on solids in the field of the high-speed water jet technology should result in considerable improvement of its performance, better adaptation to progressively more demanding environmental requirements and, consequently, more cost-saving use of the technology from the economical point of view [7].

The objective of the paper is to determine erosion effects of the pulsating water jet impinging the surface of aluminium alloy samples treated by various techniques (rough and fine milling, planing and rolling) and to discuss the influence of the initial surface topography on the final topography of the sample exposed to the pulsating water jet.

\section{Experimental facility}

The facility used for the experiment consisted basically of a high-pressure water supply system, pulsating water jet generator, robotic manipulator for traversing the jet over test samples and optical surface profilometer for the evaluation of surface characteristics of the samples.

The high-pressure water was supplied to the generator of pulsating water jet by a plunger pump able to deliver up to $65 \mathrm{l} / \mathrm{min}$ of water at the operating pressure up to $160 \mathrm{MPa}$. The generator was equipped with a commercially available fan nozzle with the equivalent orifice diameter of $2,0 \mathrm{~mm}$ and the spraying angle of $10^{\circ}$.

The generator of pulsating water jet was designed for the maximum operating pressure of $150 \mathrm{MPa}$. It consisted of a piezoelectric transducer vibrating at the operating frequency of about $20 \mathrm{kHz}$ and it was driven by an ultrasonic generator with the maximum output power of $800 \mathrm{~W}$. 
Test samples were manufactured from the aluminium alloy known as EN AW $5083 \mathrm{H} 111$. Basic properties of the alloy are given in Tab. 1. Firstly, the abrasive water jet technology was used to cut the samples from $10 \mathrm{~mm}$ thick sheet in order to eliminate thermal effects on the properties of samples $[8 \div 10]$. Dimensions of the test samples were $10 \times 60 \times 100 \mathrm{~mm}$ (Fig. 1). Secondly, the samples surface was treated by rough milling, fine milling and planing. One sample remained untreated; its surface was only affected by rolling during the aluminium sheet manufacturing. Parameters of the used technological operations are presented in Tab. 2. Then, surfaces were scanned by an optical profilometer to determine the initial surface roughness of the prepared samples (before their exposition to the pulsating water jet) $[11 \div 13]$.

Table 1 Basic properties of aluminium alloy EN AW 5083 H11

\begin{tabular}{|c|c|c|c|c|c|c|}
\hline \multicolumn{3}{|c|}{$\begin{array}{l}\text { Chemical } \\
\text { composition }\end{array}$} & \multicolumn{4}{|c|}{ Mechanical properties } \\
\hline \multirow{2}{*}{$\mathrm{Al}$} & \multirow{2}{*}{$\mathrm{Mg}$} & \multirow{2}{*}{$\mathrm{Mn}$} & \multirow{3}{*}{$\begin{array}{c}\text { Yield } \\
\text { strength } \\
\sigma_{0,2} / \mathrm{MPa} \\
\end{array}$} & \multirow{3}{*}{$\begin{array}{c}\text { Tensile } \\
\text { strength } \\
\sigma_{\mathrm{Pt}} / \mathrm{MPa}\end{array}$} & \multirow{3}{*}{$\begin{array}{c}\text { Elongation } \\
A_{50} / \mathrm{mm}\end{array}$} & \multirow{3}{*}{$\begin{array}{c}\text { Hardness } \\
\text { Brinell / } \\
\text { HB } \\
\end{array}$} \\
\hline & & & & & & \\
\hline & $\%$ & & & & & \\
\hline 4,8 & 4,5 & 0,7 & 125 & 275 & 12 & 75 \\
\hline
\end{tabular}

Table 2 Parameters of technological operations

\begin{tabular}{|c|c|}
\hline $\begin{array}{c}\text { Surface } \\
\text { treatment }\end{array}$ & Technological parameters \\
\hline Rough milling & $\begin{array}{c}\text { Milling cutter } \varnothing 63 \mathrm{~mm}, 12 \text { cutting edges, } 360 \\
\text { RPM, traversing velocity } 65 \mathrm{~mm} / \mathrm{min}\end{array}$ \\
\hline Fine milling & $\begin{array}{c}\text { Milling cutter } \varnothing 63 \mathrm{~mm}, 12 \text { cutting edges, } \\
1500 \mathrm{RPM}, \text { traversing velocity } 470 \mathrm{~mm} / \mathrm{min}\end{array}$ \\
\hline Planing & $\begin{array}{c}\text { Planing machine } 52 \text { strokes per minute, feed } \\
\text { rate } 0,12 \mathrm{~mm} \text { per stroke }\end{array}$ \\
\hline Rolling & N/A \\
\hline
\end{tabular}
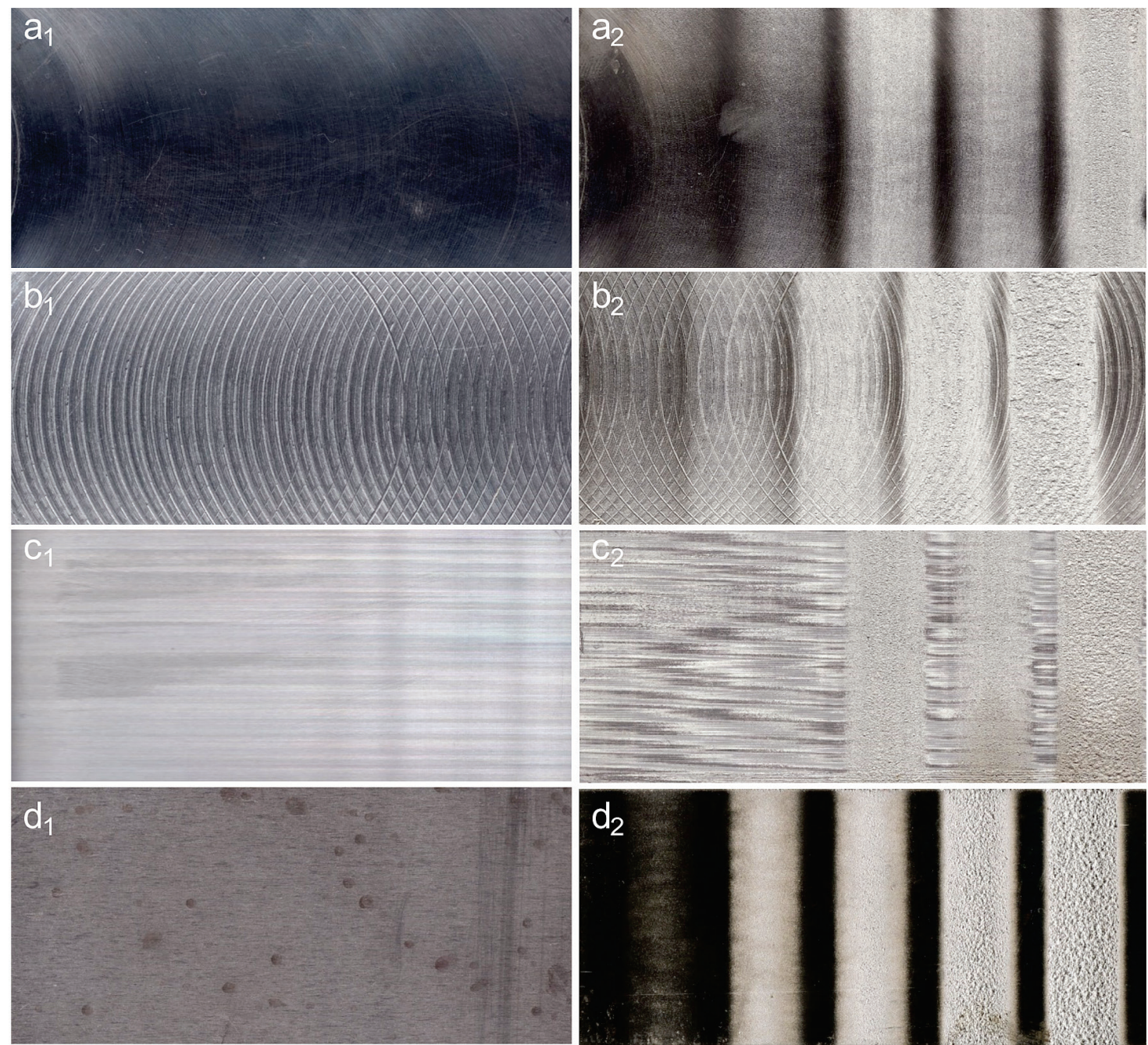

Figure 1 Left column: Appearance of initial surfaces of EN AW 5083 H111 samples after treatment by various technologies $a_{1}$ ) fine milling, $b_{1}$ ) rough milling, $c_{1}$ ) planing, $d_{1}$ ) rolling. Right column: Traces formed by PWJ on pre-treated surfaces, $a_{2}$ ) fine milling, $b_{2}$ ) rough milling, $c_{2}$ ) planing, $d_{2}$ ) rolling. Traversing velocities: $4 ; 2 ; 1 ; 0,75$ and $0,5 \mathrm{~mm} / \mathrm{s}$ (from left to right).

\section{Experimental procedure}

To enable to expose the sample surface to the effect of the pulsating water jet, the following testing procedure was developed (Fig. 2). A robotic arm ensured the nozzle movement with an exactly programmed trajectory. During experiments, the traversing velocity of the nozzle was set to 0,$5 ; 0,75 ; 1 ; 2$ and $4 \mathrm{~mm} / \mathrm{s}$; the stand-off distance was set to $55 \mathrm{~mm}$. This stand-off distance was determined as optimal for experimental conditions based on previous tests [7]. The angle of incidence was set to $90^{\circ}$.

The tests were performed at the operating pressure of $20 \mathrm{MPa}$ (the corresponding jet velocity was approx. $180 \mathrm{~m} / \mathrm{s})$. Pressure pulsations were generated in a pulsating water jet generator at the frequency of $20,09 \mathrm{kHz}$ (the readout displayed by the ultrasonic 
generator); the amplitude of vibration of the ultrasonic sonotrode tip was set to $7 \mu \mathrm{m}$.

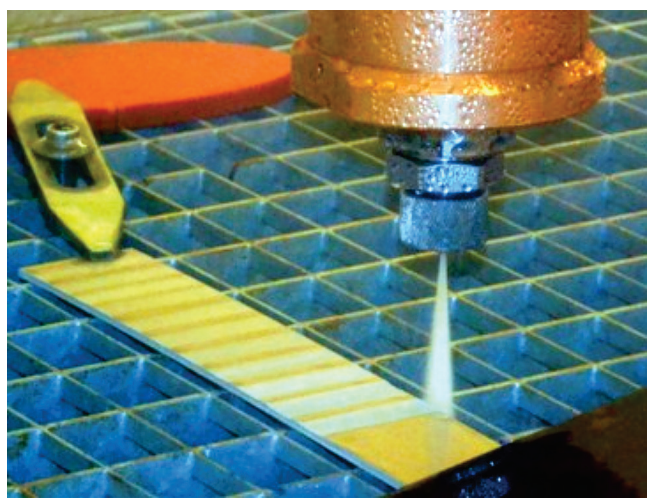

Figure 2 Pulsating water jet method on surface sample

Each sample was exposed to the action of the pulsating jet in five areas according to a predefined experimental plan based on variations of the traversing velocity of the pulsating water jet (Fig. 1).

Subsequently, the optical profilometer FRT MicroProf was used for the 3D determination of sample surfaces (Fig. 3). Measured data were processed using the SPIP software. Fig. 4 shows the areas of $40 \times 5 \mathrm{~mm}$ measured on tested surfaces. The distance of measurement points for every tested surface profile was set to $4 \mu \mathrm{m}$ in $\mathrm{y}$ direction and $250 \mu \mathrm{m}$ in $\mathrm{x}$ direction. Then, five profiles in each kerf of the obtained topografy were analysed. After averaging, the profile was analysed and the 2D surface parameter $R a$ was finally determined.

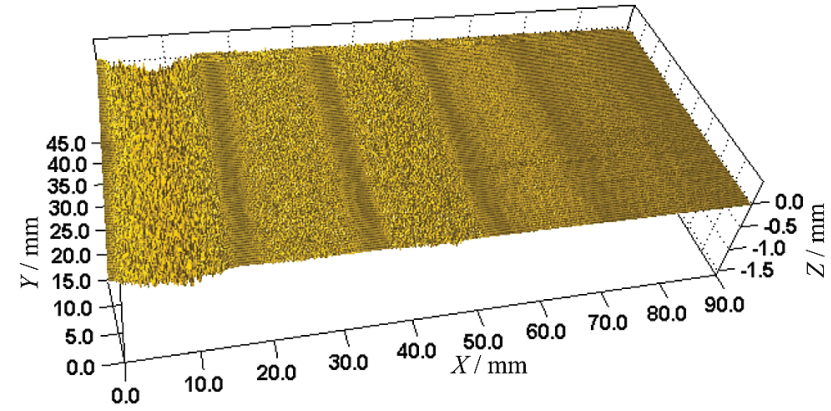

Figure $33 \mathrm{D}$ visualization of formed traces on pre-treated (planed) surface

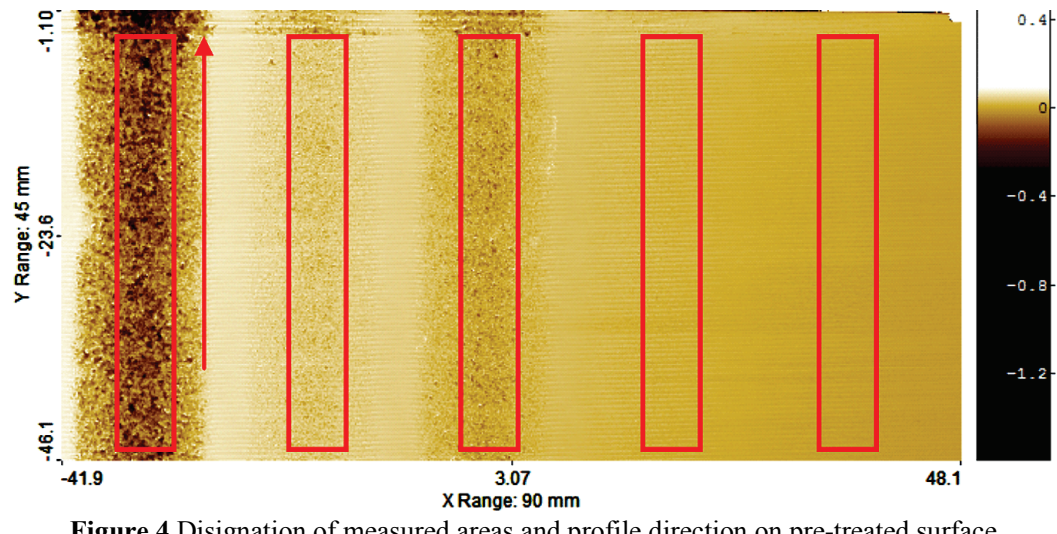

\section{Results and discussion}

The values of the parameter $R a$ in relation to the traversing velocity of the jet $v$ and the initial surface treatment of a material are presented in Tab. 3 .

Table 3 Parameters of surfaces created by pulsating water jet technology

\begin{tabular}{|c|c|c|c|c|c|c|}
\hline \multirow{2}{*}{$\begin{array}{c}\text { Surface } \\
\text { treatment }\end{array}$} & $R a_{\text {ini }} / \mu \mathrm{m}$ & \multicolumn{5}{|c|}{$R a / \mu \mathrm{m}$} \\
\cline { 2 - 7 } & Before & \multicolumn{5}{|c|}{$\nu / \mathrm{mm} / \mathrm{s}$} \\
\cline { 3 - 7 } & PWJ effect. & 4 & 2 & 1 & 0,75 & 0,5 \\
\hline Fine milling & 0,9 & 1,4 & 1,9 & 4,5 & 5,4 & 23,4 \\
\hline Rough milling & 4,5 & 7,9 & 9,2 & 14,7 & 30,8 & 60,3 \\
\hline Planing & 2,6 & 4,0 & 6,8 & 15,2 & 21,9 & 46,6 \\
\hline Rolling & 0,5 & 2,6 & 7,2 & 33,2 & 51,3 & 74,6 \\
\hline
\end{tabular}

The least roughened initial surface with an average value of $R a=0,5 \mu \mathrm{m}$ was achieved on a surface affected by the rolling technology. This value was measured in a direction perpendicular to the rolling direction. The roughness of $R a=0,9 \mu \mathrm{m}$ was achieved on a fine milled surface. The planing technology showed the roughness of $R a=2,6 \mu \mathrm{m}$ in a direction perpendicular to the direction of the cutter. The roughest surface with the value of $R a=4,5 \mu \mathrm{m}$ was created using the rough milling technology.

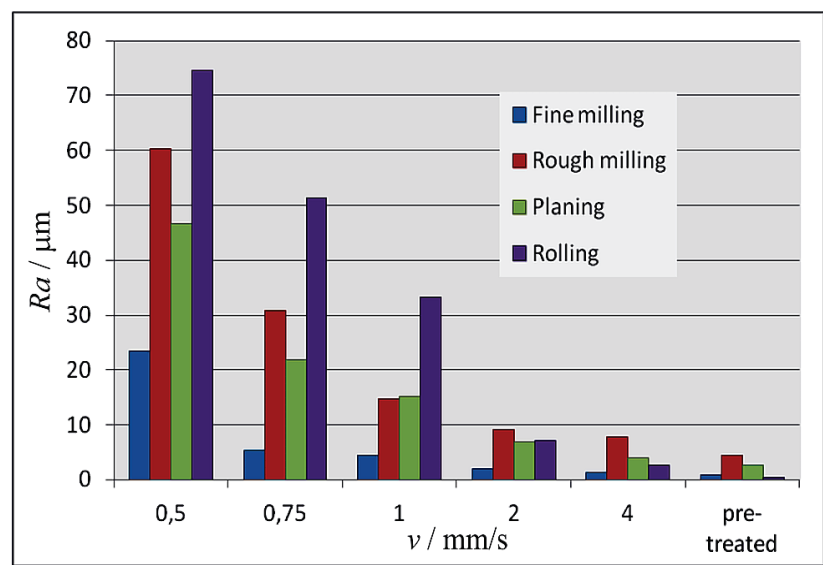

Figure 5 Effect of traversing velocity $v$ on arithmetical mean of profile $R a$

Obtained results indicate that the surface pretreatment of a material has a significant effect on the surface topography after the application of the pulsating water jet (Tab. 3). Fig. 5 shows the surface roughness $R a$ in relation to the traversing velocity $v$ on various tested surfaces. It can be observed that at the traversing velocity $v=4 \mathrm{~mm} / \mathrm{s}$, the roughness $R a$ does not really differ from its initial values. The roughest surface is the rough milled 
surface, followed by the planed surface, then the rolled surface and finally the surface treated by the fine milling. At the traversing velocity $v=2 \mathrm{~mm} / \mathrm{s}$, the PWJ has even stronger effect and roughness order of the rolled surface is changed. At the traversing velocity $v=1 \mathrm{~mm} / \mathrm{s}$, the PWJ effect on material surface is very strong and the roughness of the rolled surface increases rapidly. In contrast, the parameter $R a$ does not change considerably on both roughly and finely milled surfaces. At the traversing velocity $v=0,75 \mathrm{~mm} / \mathrm{s}$, the value of $R a$ for fine milled surface is still low. The $R a$ value increases significantly in case of other surfaces. At the lowest traversing velocity $v=0,5 \mathrm{~mm} / \mathrm{s}$, very large volume removal occurs on every surface. Accordingly, the value $R a$ increases significantly on all surfaces.

To compare the roughness of surfaces before and after treatment of the PWJ, the parameter $R a_{\text {ratio }}$ was used, where $R a$ represents the roughness of surface after the PWJ treatment and $R a_{\text {ini }}$ represents the roughness of initial surface untreated by the PWJ:

$$
R a_{\text {ratio }}=\frac{R a}{R a_{\text {ini }}} .
$$

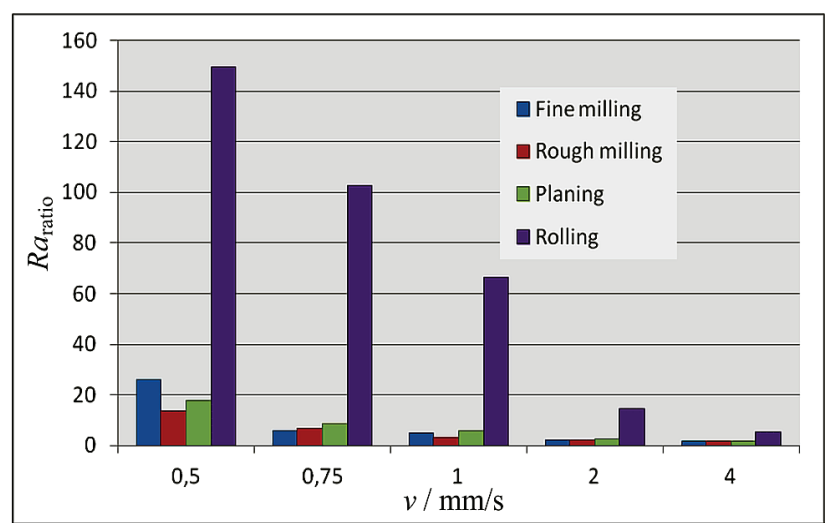

Figure 6 Relative roughness $R a_{\text {ratio }}$ between original surface and the surface affected by PWJ at different traversing velocity $v$

If we look at Fig. 6 showing the ratio of the roughness $R a$ (1) before and after the PWJ action, we can realize that the roughness of the rolled surface treated by the PWJ at the traversing velocity $v=0,5 \mathrm{~mm} / \mathrm{s}$ has increased 150 times, by other surfaces only approximately 20 times.

The assumptions that surfaces with significant roughness (after rough milling) disrupt the effect of the PWJ and that the radial flow of the liquid on the surface aligns peaks created by rough milling were confirmed. Values of roughness $R a$ are very similar to the values of the rolled and milled surfaces before the PWJ action. However, significant difference between these two surfaces occurs after using the PWJ. This could be caused by hardening of the surface layer during milling, which results in its greater resistance to the impact of the PWJ.

\section{Conclusion}

Experimental work oriented on the evaluation of effects of the pulsating water jet on surfaces treated by different technologies shows that the erosion caused by repeated impacts of water pulses depends on the initial conditions of a material surface.

Generally, the highest values of roughness after the pulsating water jet application were achieved on surfaces pre-treated by the rolling and consequent annealing which relieved stresses in surface layer. In contrast, other surface treatments based on various machining methods strengthened surface layers and thereby hindered the jet from easy penetration into the material.

Next steps of the research in this area should be oriented to the study of the influence of the surface layer hardness on the erosion process caused by effects of the pulsating water jet and the investigation of changes of properties of surface layers due to impacts of the water pulses.

\section{Acknowledgments}

Presented work has been supported by the ASCR project No. AV0Z30860518 and the project Institute of clean technologies for mining and utilization of raw materials for energy use, reg. no. CZ.1.05/2.1.00/03.0082, supported by the Research and Development for Innovations Operational Programme financed by the Structural Funds of the European Union and from the means of the State budget of the Czech Republic.

\section{References}

[1] Cook, S. S. Erosion by water hammer. // Proceedings of the R. Sot. / London, 1928, pp. 481-488. DOI: 10.1098/rspa.1928.0107

[2] Bai, C.; Chandra, S.; Daniels, B.; Ren, B.; Yan, W.; Tieu, A.; Vijay, M. Abrasive-entrained high-frequency pulsed waterjet: basic study and applications. // Proceedings of the $18^{\text {th }}$ International Conference on Water Jetting / Gdansk, 2006, pp. 325-336.

[3] Bach, F. W.; Schenk, A.; Kremer, G.; Biskup, C.; Meier, O.; Fargas, M.; Bunte, J.; Jäschke, P. Increase of erosive potential of water jets by laser pulsing. // Proceedings of the $18^{\text {th }}$ International Conference on Water Jetting / Gdansk, 2006, pp. 357-366.

[4] Foldyna, J.; Švehla, B. Method of generation of pressure pulsations and apparatus for implementation of this method. 2008, CZ patent 299412

[5] Sitek, L.; Foldyna, J.; Martinec, P. et al. Use of pulsating water jet technology for removal of concrete in repair of concrete structures. // Baltic journal of road and bridge engineering. $6, \quad 4(2011)$, pp. 235-242. DOI: 10.3846/bjrbe. 2011.30

[6] Riha, Z.; Foldyna, J. Ultrasonic pulsations of pressure in water jet cutting tool. // Technical Gazette. 19, 3(2012), pp. 487-491.

[7] Foldyna, J.; Klich, J.; Hlaváček, P. et al. Erosion of metals by pulsating water jet. // Technical Gazette. 2, 19(2012), pp. 381-386.

[8] Hreha, P.; Hloch, S.; Monka, P.; Monková, K.; Knapčíková, L.; Hlaváček, P.; Zeleňák, M.; Samardžić, I.; Kozak, D. Investigation of sandwich material surface created by abrasive water jet (AWJ) via vibration emission. // Metalurgija. 53, 1(2014), pp. 29-32.

[9] Hreha, P.; Radvanská, A.; Cárach, J.; Lehocká, D.; Monková, K.; Krolczyk, G.; Ruggiero, A.; Samardzić, I.; Kozak, D.; Hloch, S. Monitoring of focusing tube wear during abrasive waterjet (AWJ) cutting of AISI 309. // Metalurgija. 53, 4(2014), pp. 533-536. 
[10] Hreha, P.; Radvanská, A.; Hloch, S.; Peržel, V.; Królczyk, G.; Monková, K. Determination of vibration frequency depending on abrasive mass flow rate during abrasive water jet cutting. // International Journal of Advanced Manufacturing Technology, (2014) DOI: 10.1007/s00170014-6497-9

[11] Krolczyk, G. M.; Legutko, S. Experimental analysis by measurement of surface roughness variations in turning process of duplex stainless steel. // Metrology and Measurement Systems. 21, 4(2014), pp. 759-770. DOI: 10.2478/mms-2014-0060

[12] Simunovic, G.; Svalina, I.; Simunovic, K.; Saric, T.; Havrlisan, S.; Vukelic, D. Surface roughness assessing based on digital image features. // Advances in Production Engineering \& Management. 11(2016), 2, pp. 93-104. DOI: 10.14743/apem2016.2.212

[13] Wojciechowski, S.; Twardowski, P.; Wieczorowski, M. Surface texture analysis after ball end milling with various surface inclination of hardened steel. // Metrology and Measurement Systems. 21, 1(2014), pp. 145-156. DOI: 10.2478/mms-2014-0014

\section{Autor's addresses}

\section{Jiř́i Klich, Ing.}

Dagmar Klichová, Ing.

Petr Hlaváček, Ing. PhD

Institute of Geonics of the ASCR, v. v. i.

Studentská 1768, 70800 Ostrava-Poruba, Czech Republic

E-mail: jiri.klich@ugn.cas.cz 